\title{
Diversity and Path Analysis of Chilli (Capsicum spp.) Based on Morphological Traits in Northern Region of Bangladesh
}

\author{
Deen Mohammad Deepo ${ }^{1,}$ a , Aniruddha Sarker ${ }^{2, b^{*}}$, Suraiya Akter ${ }^{3, c}$, Md. Mazharul Islam 1, d, \\ Mahmudul Hasan ${ }^{4, e}$, Naheed Zeba ${ }^{4, f}$ \\ ${ }^{1}$ School of Horticultural Science, Kyungpook National University, Daegu 41566, Korea \\ ${ }^{2}$ School of Applied Biosciences, Kyungpook National University, Daegu 41566, Korea \\ ${ }^{3}$ Department of Horticulture, Sher-e-Bangla Agricultural University, Dhaka, Bangladesh \\ ${ }^{4}$ Department of Genetics and Plant Breeding, Sher-e-Bangla Agricultural University, Dhaka, Bangladesh \\ ${ }^{*}$ Corresponding author

\begin{tabular}{|c|c|}
\hline A R T I C LE INFO & A B S T R A C T \\
\hline $\begin{array}{l}\text { Keywords: } \\
\text { Phonotypic variance } \\
\text { Genotypic variance } \\
\text { Agronomic performance } \\
\text { Chilli } \\
\text { Diversity }\end{array}$ & $\begin{array}{l}\text { Genetic variability, heritability, genetic advance, correlation coefficient analysis, path coefficient analysis } \\
\text { and genetic divergence between yield and its contributing traits were estimated using fifteen (15) different } \\
\text { chilli genotypes in northern region of Bangladesh. The aim of this study is to screen out suitable parents } \\
\text { for next hybridization program. The phenotypic coefficient of variations was found slightly higher than } \\
\text { the genotypic coefficient of variations for all characters studied, indicating that the apparent variation is } \\
\text { not only genetic but also influenced by the growing environment in the expression of the traits. High } \\
\text { genotypic and phenotypic coefficient of variation was observed in length of fruit ( } 27.27 \% \text { and } 27.81 \%) \text {. } \\
\text { High heritability coupled with high genetic advance in percent of mean in fruit yield per plant }(71.23 \text { and } \\
39.38) \text {, number of fruits per plant ( } 71.26 \text { and } 31.18) \text {, weight of individual fruit ( } 88.52 \text { and } 43.80) \text {, length } \\
\text { of fruit ( } 96.13 \text { and } 70.59) \text { and diameter of fruit (79.58 and } 35.79) \text { suggested that these characters would be } \\
\text { considered for varietal selection. The correlation studies revealed that fruit yield per plant showed } \\
\text { significant positive correlation with plant height }(0.369) \text {, number of fruits per plant }(0.587) \text {, weight of } \\
\text { individual fruit ( }(0.634) \text { and length of fruit ( } 0.450) \text { which can be considered for selection of a good variety. } \\
\text { Path analysis revealed weight of individual fruit }(0.293) \text {, plant height }(0.205) \text {, number of branches per } \\
\text { plant ( } 0.186) \text {, length of fruit }(0.164) \text {, number of fruits per plant }(0.132) \text { and diameter of fruit }(0.078) \text { had } \\
\text { direct positive effect on yield per plant, indicating these traits are the main contributors to fruit yield per } \\
\text { plant. The divergence value for cluster analysis showed the highest inter-cluster distance between clusters } \\
\text { II and IV which indicates that these genotypes may provide high heterosis in hybridization and expected } \\
\text { to show wide variability in genetic architecture. }\end{array}$ \\
\hline
\end{tabular} \\ Keywords \\ Phonotypic variance \\ Genotypic variance \\ Chilli \\ Diversity

\begin{abstract}
Genetic variability, heritability, genetic advance, correlation coefficient analysis, path coefficient analysis and getic divergence between yield and its contributing traits were estimated using fifteen (15) different the genotypic coefficient of variations for all characters studied, indicating that the apparent variation is not only genetic but also influenced by the growing environment in the expression of the traits. High High heritability coupled with high genetic advance in percent of mean in fruit yield per plant (71.23 and 39.38), number of fruits per plant (71.26 and 31.18), weight of individual fruit ( 88.52 and 43.80 ), length considered for varietal selection. The correlation studies revealed that fruit yield per plant showed Path analysis revealed weight of individual fruit $(0.293)$, plant height $(0.205)$, number of branches per plant (0.186), length of fruit (0.164), number of fruits per plant (0.132) and diameter of fruit (0.078) had direct positive effect on yield per plant, indicating these traits are the main contributors to fruit yield per
\end{abstract} \\ genotypic and phenotypic coefficient of variation was observed in length of fruit (27.27\% and $27.81 \%)$. \\ of fruit (96.13 and 70.59) and diameter of fruit (79.58 and 35.79) suggested that these characters would be \\ to show wide variability in genetic architecture.
}

deeposau089@gmail.com (iD) https://orcid.org/0000-0003-1181-1266 c@adnansaad052018@gmail.com iD https://orcid.org/0000-0002-4017-5409 e@mahmudhasansau@gmail.com iD https://orcid.org/0000-0002-5781-4078

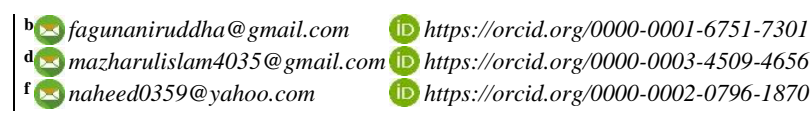

(c) () () (9) This work is licensed under Creative Commons Attribution 4.0 International License

\section{Introduction}

Chilli (Capsicum annuum L.) originated in South and Central America belongs to the family Solanaceae is a spice crop and also used as vegetable and widely cultivated throughout the world (Dias et al., 2013; Wahyuni et al., 2013). The constituents of chilli are important for its nutritional value, aroma, texture, color and it is also a good source of oleoresin which has diversified uses in process food, beverage industries and in pharmaceuticals (OsunaGarcia et al., 1998; Marin et al., 2004). Chilli, of the genus Capsicum, has more than 25 commonly used species with four cultivars groups as Chinense group (West Indies chilli), Frutescens group (bird chilli), Annuum group (hot chilli) and sweet pepper group (Nsabiyera et al., 2013). Throughout the world, chilli is generally consumed either in fresh, dried or in powder (El-Ghoraba et al., 2013).
Generally chilli is grown as a cash crop but its commercial production and it is largely concentrated in Bogra, Rangpur, Comilla, Noakhali, Faridpur, Chittagong and Mymensingh district. In Bangladesh 434,757 acres land is under its cultivation and total production of green chilli was approximately 1,549,474 metric tons (BBS, 2014). Chilli is rich in proteins, lipids, carbohydrates, fibres, mineral salts $(\mathrm{Ca}, \mathrm{P}, \mathrm{Fe})$ and in vitamins $\mathrm{A}, \mathrm{D}_{3}, \mathrm{E}$, C, K, B2 and $\mathrm{B}_{12}$ (El-Ghoraba et al., 2013). The fruits are an excellent source of health-related phytochemical compounds, such as ascorbic acid, carotenoids, tocopherols (vitamin E), flavonoids, and capsaicinoids that are very important in preventing chronic diseases such as cancer, asthma, coughs, sore throats, diabetes (Wahyuni et al., 2013); The pharmaceutical application of capsaicinoid 
is attributed to its antioxidant, anticancer, antiarthritic, and analgesic properties (Akbar et al., 2010). Moreover, the consumption of fresh fruits facilitates starchy food digestion in human body (Bhattacharya et al., 2010). It has antioxidant, antiutagenesis and hypocholesterolemic properties and also inhibits bacterial growth and platelet agglomeration (Wahyuni et al., 2013).

The systematic breeding works involved the several steps, like collecting of germplasm, assessing of genetic variability, creating of genetic variability, implementing of selection, and developing of selected genotypes to be released as commercial variety (Poehlman and Sleper, 1995 and Syukur et al., 2012). For efficient and effective breeding work, investigation and better understanding of the variability existing in a population base of crop is required so that it can be exploited by plant breeder for crop improvement. Moreover, the success of any crops improvement program depends not only on the amount of genetic variation present in a crop but also on magnitude of variation which is heritable from the parent to the progeny (Bello et al., 2014). A wide range of variability is available in chilli genotypes which provide great scope for improving fruit yield through systematic breeding. Estimation of genetic variability present in the germplasm of a crop is a pre-requisite for designing effective breeding programme (Parkash, 2012).

Several researchers observed that phenotypic coefficient of variation (PCV) to be higher than genotypic coefficient of variation (GCV) for all the studied traits (Kadwey et al., 2016; Gupta et al., 2009 and Bendale et al., 2006). Heritability was found to be very high for fruit yield per plant, seed yield per plant, fruit length, fruit weight of green chilli and fruit yield per hectare (Wilson and Philip, 2009 and Bharadwaj et al., 2007). In order to benefit transgressive segregation, the knowledge of genetic distance between parents is necessary (Lahbib et al., 2012 and Khodadadi et al., 2011). The information the degree of genetic divergence is essential for the breeder to choose the right type of parents for purposeful hybridization in heterosis breeding (Khodadabi et al., 2011 and Farhad et al., 2010). More diverse the parents within a reasonable range, better are the chances of improving economic characters in the offspring. The critical assessment of nature and magnitude of variability in the germplasm stock is one of the important pre-requisites for formulating effective breeding methods (Krishna et al., 2007). The choice of the most suitable breeding method for the rational improvement of yield and its components in any crop largely depends upon the genetic variability, correlations and association between qualitative and quantitative characters and heritability estimates.

Considering the entire situation, the present study was steered for genetic diversity analysis of chilli with the following specific objectives; to compare the yield contributing characters and yield potentiality of different chilli genotypes; the nature of association of traits, direct and indirect relation between yield contributing characters and yield of different chilli genotypes; to screen out the suitable parents group which are likely to provide superior segregates on hybridization and to assess the magnitude of genetic divergence in genotypes for identifying the genetically divergent parents to use them in future breeding program.

\section{Materials and Method}

\section{Experimental Site}

The experiment was conducted at the Northern Region of Bangladesh from November 2015 to April 2016 in rabi season. The experimental area was under the subtropical monsoon climate zone, which was characterized by heavy rainfall, high humidity, high temperature and relatively long day during the growing season. The soil was sandy loam in texture having $\mathrm{pH}$ 5.47-5.63. The mean temperature of the growing period was $26.43^{\circ} \mathrm{C}$ with average maximum and minimum being $36^{\circ} \mathrm{C}$ and $20.54^{\circ} \mathrm{C}$, respectively.

\section{Plant Materials}

Fifteen genotypes of chilli were used in this study which was collected from Department of Genetics and Plant Breeding, Sher-e-Bangla Agricultural University, Dhaka and Plant Genetic Resources Centre (PGRC) of Bangladesh Agricultural Research Institute (BARI), Joydebpur, Gazipur and Farmers' field of Northern districts of Bangladesh (Table 1).

\section{Field Managements}

All the fertilizers were applied as recommended dozes following appropriate application timing and method. The recommended dosage of Urea, TSP, MoP, Gypsum and Znic sulphate was applied in field at the rate of 210, 300, 200,100 and $15 \mathrm{Kg} / \mathrm{ha}$ respectively. Irrigation was applied once a week at emergence and every two weeks at flowering and fruit production. Chemical (Sevine, Marshal and deltanet) and cultural practices (hand picking and remove infected plant part) were applied to control insect pest. Tender fruits were harvested two times per week to estimate fruit yield while mature fruits were harvested when fruits turned to loss green color and dry fruit for seed yield parameter.

\section{Data Collection and Analysis}

Data for different plant parameters were recorded from 5 plants of each genotype. Genotypic and phenotypic variance was estimated by the formula used by Johnson et al. (1955). Heritability and genetic advance were measured using the formula given by Singh and Chaudhary, 1985. Cluster Analysis (CA) was done by using GENSTAT 5.13 and Microsoft Excel 2007 software. Data of ten characters were subjected to analysis of variance (ANOVA) using MSTATC software program to test the presence of significant differences among accessions for the traits measured. It was also measure of mean, range, $\mathrm{CV}$, standard deviation by this software. Phenotypic coefficient of variation (PCV), genotypic coefficient of variation (GCV), broad-sense heritability $\left(\mathrm{H}^{2}\right)$ and expected genetic advance as percentage to mean (GAM) were computed. The phenotypic and genotypic correlation coefficients obtained from correlation study, were further partitioned into direct and indirect effects with the help of path coefficient analysis as suggested by Wright, 1921 and applied in plant breeding by Dewey and Lu, 1959. Diversity analysis was estimated from measured quantitative traits. Duncan's Multiple Range (DMRT) was employed to identify genotypes that are significantly different from each other. Descriptive statistic was used for qualitative traits data. 
Table 1. Chili genotypes and their basic information's

\begin{tabular}{c|lcl}
\hline Genotypes & Name of genotypes & Genotypes & Name of genotypes \\
\hline $\mathrm{G}_{1}$ & Ca 001 & $\mathrm{G}_{9}$ & SRCO 1 \\
$\mathrm{G}_{2}$ & Ca 002 & $\mathrm{G}_{10}$ & SRCO 2 \\
$\mathrm{G}_{3}$ & Special chili of Bogra & $\mathrm{G}_{11}$ & SRCO 9 \\
$\mathrm{G}_{4}$ & Surjamukhi IMP & $\mathrm{G}_{12}$ & SRC 13 \\
$\mathrm{G}_{5}$ & Black Lady (local variety) & $\mathrm{G}_{13}$ & CO 613 \\
$\mathrm{G}_{6}$ & Local 1 variety & $\mathrm{G}_{14}$ & SRCO 5 \\
$\mathrm{G}_{7}$ & HP 1029 & $\mathrm{G}_{15}$ & Hot Morich of Bogra \\
$\mathrm{G}_{8}$ & CO 610 & & \\
\hline
\end{tabular}

* G1 and G2 = Exotic cultivar; G7 - G14 = Farmer cultivars that collected from different districts of North Bengal of Bangladesh and Sher-e-Bangla Agricultural University (SAU), Bangladesh.

Table 2. Estimation of variance parameters for ten characters in chilli genotypes

\begin{tabular}{|c|c|c|c|c|c|c|c|c|c|c|c|}
\hline Traits & & Min & Iax & $n$ & $\mathrm{O}^{2} \mathrm{~g}$ & $\mathrm{O}_{\mathrm{P}}^{2}$ & $\mathrm{CV}$ & $\mathrm{PCV}$ & $\mathrm{h}^{2}{ }_{\mathrm{b}}$ & GA & $A$ \\
\hline D & & & 7 & & 3.23 & 10.22 & 3.85 & 6 & 31.60 & 2.6 & 5.71 \\
\hline & & & 57 & 73 & & 73 & .73 & & $H 1$ & 4 & .16 \\
\hline & & & & & & & 9.12 & & & & \\
\hline & 3 & 54.40 & 88.73 & 68.70 & 92 & 129.76 & 13.99 & 16.57 & 26 & 21.42 & 31.18 \\
\hline & & & & & & & 63 & 74 & & & .80 \\
\hline & & & & 4 & & & 27.27 & 27.81 & & 5 & 70.59 \\
\hline & & & & & & & 15.20 & 17.04 & & 2.58 & 35.79 \\
\hline & 1 & 4 & & 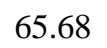 & 33 & & 8.83 & 12.70 & & 10.64 & 16.20 \\
\hline & & 62.44 & & 67.68 & & & 4.93 & 8.92 & 30.54 & 4.88 & 7.19 \\
\hline Yield/plant (g) & $12037.511 * *$ & $242 . .89$ & 427.44 & 336.41 & 3536.30 & 4964.91 & 17.68 & 20.95 & 71.23 & 132.49 & 39.38 \\
\hline
\end{tabular}

1: (\% mean), ${ }^{* *}$ Significant at $1 \%, *$ Significant at $5 \%$

\section{Results}

The mean performance of the genotypes, estimated variability components viz. phenotypic and genotypic variance, phenotypic coefficient of variation (PCV) and genotypic coefficient of variation (GCV), heritability in broad sense and genetic advance as percent of means (GA\%) for 10 characters are presented in Table 2. Days to 1st flowering refers to phenotypic variance (10.22) was higher than the genotypic variance (3.23) supported by high difference between phenotypic $(6.84 \%)$ and genotypic $(3.85 \%)$ co-efficient of variation with low heritability $(31.60 \%)$ and moderate genetic advance in percentage of mean (5.71). Plant height refers to phenotypic variance (73.52) was higher than the genotypic variance (40.73) supported by moderate difference between phenotypic $(8.73 \%)$ and genotypic $(11.73 \%)$ co-efficient of variation with moderate heritability $(55.41 \%)$ was observed in plant height attached with high genetic advance in percentage of mean (17.16). Number of branches/plant refers to phenotypic variance (1.17) was higher than the genotypic variance (0.50) supported by high difference between phenotypic (13.94\%) and genotypic (9.12\%) co-efficient of variation with moderate heritability $(42.83 \%)$ and high genetic advance in percentage of mean (15.76). Number of fruits/plant refers to phenotypic variance (129.64) was higher than the genotypic variance (92.38) supported by high difference between phenotypic $(16.57 \%)$ and genotypic $(13.99 \%)$ co-efficient of variation with high heritability $(71.26 \%)$ and high genetic advance in percentage of mean (31.18). Weight of individual fruit refers to phenotypic variance $(0.85)$ was higher than the genotypic variance (0.76) supported by low difference between phenotypic $(18.74 \%)$ and genotypic $(17.63 \%)$ co-efficient of variation with high heritability $(88.52 \%)$ and high genetic advance in percentage of mean (43.80). Length of fruit refers to phenotypic variance (3.31) was higher than the genotypic variance (3.08) supported by low difference between phenotypic $(27.81 \%)$ and genotypic $(27.27 \%)$ co-efficient of variation with high heritability $(96.13 \%)$ and high genetic advance in percentage of mean (70.59). Diameter of fruit refers to phenotypic variance (1.51) was higher than the genotypic variance (1.20) supported by low difference between phenotypic (17.04\%) and genotypic (15.20\%) coefficient of variation with high heritability $(79.58 \%)$ and high genetic advance in percentage of mean (35.79). Number of seeds per fruit refers to phenotypic variance (69.56) was higher than the genotypic variance (33.62) supported by high difference between phenotypic (12.70\%) and genotypic $(8.83 \%)$ co-efficient of variation with moderate heritability $(48.33 \%)$ and high genetic advance in percentage of mean (16.20). Weight of 1000 seeds refers to phenotypic variance (36.63) was higher than the genotypic variance (11.19) supported by high difference between phenotypic $(8.92 \%)$ and genotypic $(4.93 \%)$ co-efficient of variation with low heritability $(30.54 \%)$ and moderate genetic advance in percentage of mean (7.19). Yield/plant refers to phenotypic variance (4964.91) was higher than the genotypic variance (3536.30) supported by high difference between phenotypic $(20.95 \%)$ and genotypic $(17.68 \%)$ coefficient of variation with high heritability $(71.23 \%)$ and low genetic advance in percentage of mean (39.38).

Correlation coefficient was worked out to assist in selection procedure which suggests the association of traits with yield. The association among the component traits listed in Tables 3 . In correlation study, highly significant positive association was recorded for days to 1 st flowering of chilli genotypes with weight of individual fruit (0.446), whereas the non-significant positive association was recorded for plant height $(0.142)$, number of branches/plant (0.158), length of fruit (0.032), diameter of fruit (0.273) and yield/plant (0.154). 
Table 3. Correlation matrix for yield attributes and yields of different chilli genotypes

\begin{tabular}{|c|c|c|c|c|c|c|c|c|c|c|}
\hline Characters & $\overline{\mathrm{DF}}$ & $\mathrm{PH}$ & NBP & NFP & WIF & $\mathrm{LF}$ & $\overline{\mathrm{DF}}$ & $\mathrm{NSF}$ & WS & YP \\
\hline$\overline{D F}$ & 1 & & & & & & & & & \\
\hline PH & 0.142 & 1 & & & & & & & & \\
\hline NBP & 0.158 & $0.365 * *$ & 1 & & & & & & & \\
\hline NFP & -0.24 & $0.360 *$ & 0.229 & 1 & & & & & & \\
\hline WIF & $0.446^{* *}$ & 0.145 & -0.03 & -0.245 & 1 & & & & & \\
\hline $\mathrm{LF}$ & 0.032 & 0.161 & -0.032 & $0.376^{* *} *$ & 0.191 & 1 & & & & \\
\hline DF & 0.273 & 0.065 & -0.107 & $-0.353^{*}$ & 0.2 & $-0.329 *$ & 1 & & & \\
\hline NSF & $-0.319 *$ & -0.001 & 0.188 & 0.275 & -0.205 & -0.021 & -0.175 & 1 & & \\
\hline WS & -0.186 & 0.07 & -0.027 & -0.222 & $0.365^{* *}$ & -0.118 & -0.062 & -0.017 & 1 & \\
\hline YP & 0.154 & $0.369 * *$ & 0.149 & $0.587 * *$ & $0.634 * *$ & $0.450 * *$ & -0.119 & 0.048 & 0.119 & 1 \\
\hline
\end{tabular}

DF: Days to $1^{\text {st }}$ flowering, PH: Plant height $(\mathrm{cm})$, NBP: Number of branches per plant, NFP: Number of fruits / plant, WIF: Weight of individual fruit (g), LF: Length of fruit (cm), DF: Diameter of fruit (mm), NSF: Number of seeds / fruit, WS: Weight of 1000 seeds $(\mathrm{g})$, YP: Yield per plant, ** = Significant at 0.01 level of probability; $*$ = Significant at 0.05 level of probability

Table 4. Path coefficients for yield attributes and yields of different chilli genotypes

\begin{tabular}{l|cccccccccc}
\hline Characters & DF & PH & NBP & NFP & WIF & LF & DF & NSF & WS & YP \\
\hline DF & -0.148 & 0.379 & 0.234 & -0.063 & -0.211 & 0.136 & -0.142 & 0.167 & -0.198 & 0.154 \\
PH & 0.156 & 0.205 & -0.102 & -0.132 & 0.198 & 0.219 & 0.169 & -0.267 & -0.077 & 0.369 \\
NBP & -0.231 & 0.123 & 0.186 & 0.208 & -0.229 & -0.289 & 0.125 & 0.165 & 0.091 & 0.149 \\
NFP & 0.176 & -0.067 & 0.218 & 0.132 & 0.169 & 0.109 & -0.157 & 0.045 & -0.038 & 0.587 \\
WIF & 0.187 & 0.213 & -0.029 & -0.138 & 0.293 & -0.084 & 0.125 & -0.189 & 0.256 & 0.634 \\
LF & -0.113 & -0.158 & 0.228 & 0.073 & -0.104 & 0.164 & -0.072 & 0.19 & 0.242 & 0.45 \\
DF & 0.133 & 0.094 & -0.188 & -0.152 & 0.055 & -0.212 & 0.078 & 0.055 & 0.018 & -0.119 \\
NSF & -0.152 & 0.073 & 0.097 & 0.128 & 0.038 & 0.131 & 0.133 & -0.133 & -0.267 & 0.048 \\
WS & 0.184 & -0.109 & -0.138 & -0.055 & 0.289 & -0.044 & -0.105 & 0.308 & -0.211 & 0.119 \\
YP & 0.154 & $0.369 * *$ & 0.149 & $0.587 * *$ & $0.634 * *$ & $0.450 * *$ & -0.119 & 0.048 & 0.119 & 1 \\
\hline
\end{tabular}

DF: Days to $1^{\text {st }}$ flowering, PH: Plant height (cm), NBP: Number of branches per plant, NFP: Number of fruits / plant, WIF: Weight of individual fruit (g), LF: Length of fruit (cm), DF: Diameter of fruit (mm), NSF: Number of seeds / fruit, WS: Weight of 1000 seeds (g), YP: Yield per plant, Residual effect $=0.3803$

Highly significant positive association was recorded for plant height of chilli genotypes with number of branches/plant (0.365), number of fruits/plant (0.360) and yield/plant (0.369), while the non-significant positive association was recorded for days to 1 st flowering (0.142), weight of individual fruit (0.145), length of fruit $(0.161)$, diameter of fruit (0.065) and weight of 1000 seeds $(0.070)$. Highly significant positive association was recorded for number of branches per plant of chilli genotypes with plant height $(0.365)$, while the non-significant positive association was recorded for days to 1 st flowering (0.158), number of fruits/plant (0.229), number of seeds/fruit (0.188) and yield/plant (0.149). Highly significant positive association was recorded for number of fruits/plant of chilli genotypes with plant height (0.360), length of fruit (0.376) and yield/plant (0.587), while the non-significant positive association was recorded for number of branches/plant (0.229) and number of seeds/fruit (0.275) Highly significant positive association was recorded for weight of individual fruit of chilli genotypes with days to 1 st flowering (0.446), weight of 1000 seeds (0.365) and yield/plant (0.634), whereas the non-significant positive association was recorded for days plant height (0.145), length of fruit (0.191) and diameter of fruit (0.200). Highly significant positive association was recorded for length of fruit of chilli genotypes with number of fruits/plant (0.376) and yield/plant (0.450), while the non-significant positive association was recorded for days to 1st flowering (0.032), plant height (0.161) and weight of individual fruit (0.191). Non-significant positive association was recorded for diameter of fruit with days to 1 st flowering (0.273), plant height (0.065) and weight of individual fruit (0.200). On the other hand, highly significant negative association was recorded for number of fruits/plant $(-0.353)$ and length of fruit (-0.329). Non-significant positive association was recorded for number of seeds per fruit for number of branches per plant $(0.188)$, number of fruits per plant $(0.275)$ and yield per plant (0.048). Highly significant positive association was recorded for weight of 1000 seeds of chilli genotypes with weight of individual fruit $(0.365)$, while the non-significant positive association was recorded for plant height (0.070) and yield/plant (0.119). Highly significant positive association was recorded for yield per plant of chilli genotypes with plant height (0.369), number of fruits/plant (0.587), weight of individual fruit (0.634) and length of fruit (0.450), while the non-significant positive association was recorded for days to 1 st flowering (0.154), number of branches/plant (0.149), number of seeds/fruit (0.048) and weight of 1000 seeds $(0.119)$.

The mutual relationship of component characters might vary both in magnitude and direction and the simple correlation coefficient may not provide the exact relationship between yield and yield attributes. Therefore, it is necessary to conduct path coefficient analysis which permits a critical examination of specific direct and indirect effects of characters and measures their relative intensity in determining the ultimate goal yield. Path coefficient analysis (Table 4) revealed that days to 1 st flowering had negative direct effect (0.148), plant height had positive direct effect (0.205), number of branches/plant had positive direct effect (0.186), number of fruits/plant had positive direct effect (0.132), weight of individual fruit had positive 
direct effect (0.293), length of fruit had positive direct effect (0.164), diameter of fruit had positive direct effect (0.078), number of seeds/fruit had negative direct effect ($0.133)$ and weight of 1000 seeds had negative direct effect $(-0.211)$ on yield/plant.

The clustering pattern of all genotypes has been presented in (Table 5). The cluster I comprised eight genotypes including G2, G3, G4, G6, G8, G9, G11 and G13. Cluster II contained three genotypes namely, G7, G10 and G14. Cluster III consisted of three genotypes viz., G1, G5 and G15. Cluster IV was composed of single genotype G12 indicated that this genotype is totally different from other genotypes used in this study. The intra cluster (Bold) and inter cluster divergence (average $\mathrm{D}^{2}$ values) of all clusters have been presented in Table 6 . Intra cluster average $D^{2}$ values ranged from 0.00 to 0.6732 . It recorded maximum (0.6732) in cluster IV with one genotype followed by 0.4765 in cluster III with three genotypes. Inter cluster average $\mathrm{D}^{2}$ values were higher (12.541) between cluster II and cluster IV followed by 9.672 between cluster II and cluster III. The minimum inter cluster value for all the characters were as 4.023 between cluster I and cluster III.

Table 5. Distribution of 15 genotypes in different clusters

\begin{tabular}{c|ccc}
\hline Cluster & Members & Chilli Genotypes & Name of genotypes \\
\hline I & 8 & $\mathrm{G}_{2}, \mathrm{G}_{3}, \mathrm{G}_{4}, \mathrm{G}_{6}, \mathrm{G}_{8}, \mathrm{G}_{9}$, & Ca 002, Special chilli of Bogra, Surjamukhi IMP, Local 1, \\
II & 3 & $\mathrm{G}_{11}$ and $\mathrm{G}_{13}$ & CO 610, SRCO 1, SRCO 9 and CO 613 \\
III & 3 & $\mathrm{G}_{7}, \mathrm{G}_{10}$ and $\mathrm{G}_{14}$ & HP 1029, SRCO 2 and SRCO 5 \\
IV & 1 & $\mathrm{G}_{1}, \mathrm{G}_{5}$ and $\mathrm{G}_{15}$ & Ca 001, Black Lady and Hot Morich of Bogra \\
\hline
\end{tabular}

Table 6. Intra (Bold) and inter cluster distances $\left(\mathrm{D}^{2}\right)$ for 15 genotypes

\begin{tabular}{c|cccc}
\hline Cluster & I & II & III & IV \\
\hline I & 0.000 & & & \\
II & 5.452 & 0.1574 & & \\
III & 4.023 & 9.672 & 0.4765 & 0.6732 \\
IV & 5.134 & 12.541 & 8.679 & \\
\hline
\end{tabular}

\section{Discussion}

The analysis of variance revealed significant difference among the genotypes for all the characters (Table 2). The existence of high variability for different characters among chilli genotypes has earlier studied by Kumary and Rajmony (2004). The variation was highest for fruit yield per plant (242.89-427.44 g) and narrow range of variability was observed for number of branches per plant (6.33-9.07). The similar finding was also reported by Singh et al. (2013) and Kadwey et al. (2016). The highest phenotypic variances were calculated for fruit yield per plant (4964.91) followed by number of fruits per plant (129.76) and plant height (73.52) while the lowest value was recorded for weight of individual fruit (0.85) followed by number of branches per plant (1.17) and fruit diameter (1.51). The genotypic variance ranged from 0.01 (Number of branches per plant) to 3536.30 (fruit yield per plant). This suggested the scope for improvement of these characters through selection. The phenotypic coefficient of variation was higher than the genotypic coefficient of variation for all the characters studied. According to Sivasubramaniah and Meron (1973) PCV and GCV values greater than $20 \%$ are regarded as high, values between $10 \%$ and $20 \%$ to be medium whereas values less than $10 \%$ are considered to be low. Based on this delineation among all characters exhibiting high degree of genotypic and phenotypic coefficients of variation was in length of fruit $(27.27 \%$ and $27.81 \%$ ) and this closer magnitude of genotypic and phenotypic coefficients of variation indicated that a greater role was played by genotypes rather than environment. Moderate GCV and PCV were found in number of fruits per plant (13.99\% and $16.57 \%$ ) weight of individual fruit (17.63) and diameter of fruit (15.20\% and 17.04\%) (Table 2). Medium PCV and GCV value suggests that these characters are controlled more of by the genetic factors.
Hence, these characters amenable to selection for further improvement. The eminent scientist Johnson et al. (1955) suggested that high heritability combined with high genetic advance is indicative of additive gene action and selection based on these parameters would be more reliable. In the present investigation, high heritability estimates in conjunction with high genetic advances were observed for fruit yield per plant, number of fruits per plant, weight of individual fruit, length of fruit and diameter of fruit. Similar findings were also studied by Choudhary and Samadia (2004) and Ukkund et al. (2007) who reported high heritability and high genetic advance for fruits per plant and fruit weight.

Plant breeders always look for genetic variation among characters to select the desirable types which are highly correlated among themselves and with yield and the analysis of the relationship among these characters are vital for selection criteria. Fruit yield has shown positive and significant correlations with plant height (0.369), number of fruits per plant (0.587), weight of individual fruit (0.634) and length of fruit (0.450). Fruit yield per plant has also shown negatively and insignificantly correlated with diameter of fruit (-0.119). The findings of positive correlation are also confirmatory with Patel and Patel (2014), Yatung et al. (2014) and Dolkar et al. (2015), Patel et al. (2015), Sharma and Sridevi (2016), and Mamatha et al. (2016). In contrast, fruit yield showed positive and nonsignificant correlation with days to $1^{\text {st }}$ flowering (0.154), number of branches per plant (0.149), number of seeds per plant (0.048) and weight of 1000 seeds (0.119).

The path coefficient analysis (Table 4) showed that, weight of individual fruit (0.293) had highest positive direct effects on fruit yield per plant followed by plant height (0.205), number of branches per plant (0.186), 
length of fruit (0.164), number of fruits per plant (0.132) and diameter of fruit (0.078) which is in agreement with Yatung et al., (2014), Pandit and Adhikary (2014), Patel et al., (2015), Mamatha et al., (2016) and Sharma and Sridevi (2016). On the other hand, the direct negative effects were recorded for days to $1^{\text {st }}$ flowering (-0.148), number of seeds per fruit (-0.133) and weight of thousand seeds $(-0.211)$ on fruit yield per plant. Hence, direct selection for weight of individual fruit was suggested to improve yield.

All 15 genotypes grouped into four clusters on the basis of yield components studied. Clustering of genotypes on the basis of genetic diversity would help the breeder for selecting diverse plants for using in hybridization under further breeding program. Clustering pattern was not influenced by geographical distribution of genotypes. Karad et al. (2002), reported eight clusters with 40 genotypes. Manju and Sreelathakumary (2004) reported six clusters with 32 accessions. Senapati et al. (2003) reported six clusters in 20 diverse genotypes of chili and Amarul Junior et al. (2005) reported eight distinct grouped in 50 accessions of chili. Genotypes from these four clusters if involve in hybridization may occur a wide spectrum of segregating population as genetic diversity is very distinct among the groups. The selection of diverge genotype from cluster would produce a broad spectrum of variability for morphological and quality traits studied which may enable further selection and improvement.

\section{Conclusion}

Genetic advancement in chilli is possible through varietal selection exercised for the number of fruits per plant, weight of individual fruit, length of fruit, diameter of fruit and fruit yield per plant which showed high heritability coupled with high genetic advance. In our study, fruit yield has shown positive and significant correlations with plant height, number of fruits per plant, weight of individual fruit and length of fruit. Therefore, plant height, number of fruits per plant, weight of individual fruit and length of fruit were the most important traits for improving the genotypes for higher fruit yield and may be applied for selection in chilli productivity. Path analysis revealed that, the highest direct positive effect on fruit yield was exerted by weight of individual fruit, plant height, number of branches per plant, length of fruit, and number of fruits per plant and diameter of fruit. Thus, on the basis of current result, weight of individual fruit, plant height, number of branches per plant, length of fruit, and number of fruits per plant and diameter of fruit could be the most important yield component characters which might be selected for yield improvement. The hybrids of genotypes with maximum distance resulted in high yield and thus the cross between the genotypes from cluster II and IV can be used in chilli breeding to achieve maximum heterosis. Minimum distance was between the genotypes of cluster I and III which can be used for backcrossing programs.

\section{References}

Akbar N, Ahmad H, Ghafoor S, Begum K, Afridi SG, Muhammad I, Khan IA. 2010. Estimation of genetic diversity in capsicum germplasm using Randomly Amplified Polymorphic DNA. Asian J. Agric. Sci. 2: 53-56.

Amarul Junior AT, Rodrigues R, Sudre CP, Riva EM, Karasawa M. 2005. Genetic divergence between 'chilli' and sweet pepper accessions using multivariate techniques. Horticultura Brasileira. 23 (1): 22-27.

BBS. 2014. Year book of agricultural statistics of Bangladesh. Bangladesh Bureau of Statistics, Planning division, Ministry of planning, Govt. of the Peoples Republic of Bangladesh, Dhaka. p.156.

Bello OB, Ige SA, Azeez MA, Afolabi MS, Abdulmaliq SY, Mahamood J. 2014. Heritability and genetic advance for yield and its component character in chilli. Int. J. Plant Res. 2: 138145.

Bendale VW, Palsuledesai MR, Bhave SG, Sawant SS, Desai SS. 2006. Genetic evaluation of some economic traits in chilli. Crop Res. 31: 401-403

Bharadwaj DN, Singh SK, Singh HL. 2007. Genetic variability an association of component characters for yield in chilli. Intl. J. Plant Sci. 2: 93-96

Bhattacharya A, Chattopadhyay A, Mazumdar D, Chakravarty A, Pal S. 2010. Antioxidant constituents and enzyme activities in chilli peppers. Intl. J. Veg. Sci. 16(3): 201-211.

Choudhary BS, Samadia DK. 2004. Variability and character association in chilli landraces and genotypes under arid environment. Indian J of Hort. 61:132-136

Dewey DR, Lu KH. 1959. A correlation and path coefficient analysis of components of crested wheatgrass seed production. Agronomy Journal. 51 (9): 515-518.

Dias GB, Gomes VM, Moraes TMS, Zottich UP, Rabelo GR, Carvalho AO, Moulin M, Goncalves LSA, Rodrigues R, Da Cunha M. 2013. Characterization of Capsicum species using anatomical and molecular data. Gene. Mol. Res. 4 (2): 1-14.

Dolkar R, Madalageri MB, Manjunath G. 2015. Correlation and path analysis for growth, earliness, yield and quality parameters in Chilli (Capsicum annuum L.). Hort. Flora Res. Spectrum. 4 (3): 268-272.

El-Ghoraba AH, Javedb Q, Anjumb FM, Hamedc SF, Shaabana HA. 2013. Pakistani bell pepper (Capsicum annum L.): chemical compositions and its antioxidant activity. Int. J. Food Prop. 16 (1):18-32.

Farhad M, Hasanuzzaman M, Biswas BK, Arifuzzaman M, Islam MM. 2010. Genetic divergence in chilli. Ban. Res Pub. J. 3 (3): 1045-1051.

Gupta AM, Singh D, Kumar A. 2009. Genetic variability, genetic advance and correlation in chilli. Indian J. Agril. Sci. 79: 221223.

Johnson HW, Robinson HF, Comstock RE. 1955. Genotypic and phenotypic correlations in soybeans and their implications in selection. Agron J. 47: 477-483.

Kadwey S, Ashwini D, Sunil P. 2016. Genotypes performance and genetic variability studies in Hot Chilli. Indian J. Agril. Res. 50 (1): 56-60.

Karad SR, Raikar GR, Navale PA. 2002. Genetic divergence in chilli. J. Maharashtra Agril. Univ. 27 (2): 143-145.

Khodadabi M, Fotokian MH, Miransari M. 2011. Genetic diversity of wheat genotypes based on cluster and principal component analyses for breeding strategies. Australian J Crop Sci. 5 (1): 17-24.

Krishna UC, Madalageri MB, Patil MP, Ravindra M, Kotlkal YK. 2007. Variability studies in green chilli (Capsicum annuum L.) Karnataka J. Agril. Sci. 20: 102-104. 
Kumary S, Rajamony L. 2004. Variability, heritability and genetic advance in chilli. J. of Trop. Agril. 42 (1-2): 35-37

Lahbib K, Bnejdi F, Gazzah EI. 2012. Genetic diversity evaluation of pepper in Tunisia based on morphologic characters. African J. Agric. Res. 7 (23): 3413-3417.

Mamatha A, Devaraju PCU, Srinivasa V. 2016. Genetic correlation and path coefficient analysis In Chilli (Capsicum annuит L.) genotypes under hill zone of Karnataka. The Bioscan. 11 (3):1995-1998.

Manju PR, Sreelathakumary I. 2004. Genetic divergence in hot chilli (Capsicum chinense Jacq). Capsicum and Eggplant Newsl. pp. 69-72.

Marin A, Ferreres F, Tomas Barberan FA, Gil M. 2004 Characterization and quantization of antioxidant constituents of sweet pepper (Capsicum annuum L.) J. Agril. Food Chem. 52 (12): 3861-3869.

Nsabiyera V, Logose M, Ochwo-Ssemakula M, Sseruwagi P, Gibson P, Ojiewo CO. 2013. Morphological characterization of local and exotic hot pepper of Uganda. Bioremed. Biodiver. Bioavail. 7 (1): 22-32.

Osuna-García JA, Wall MW, Waddell CA. 1998. Endogenous levels of tocopherols and ascorbic acid during fruits ripening of New Mexican-type chilli (Capsicum annuum L.) cultivars. J. Agril \& Food Chem. 46 (12): 5093-5096.

Pandit MK, Adhikary S. 2014. Variability and heritability estimates in some reproductive characters and yield in Chilli (Capsicum annuum L.). Int. J. of Plant \& Soil Sci, 3 (7): 845853.

Parkash C. 2012. Estimation of genetic variability and implications of direct effects of different traits on leaf yield in bathua (Chenopodium album). Indian J. Agri. Sci. 82: 71-74.

Patel DK, and Patel JR. 2014. Correlation and path analysis in Chilli (Capsicum annuum var. Longum) Trends in Bio. 7 (24): 4422-4425.
Patel DK, Patel BR, Patel JR, Kuchhadiya GV. 2015. Genetic variability and character association studies for green fruit yield and quality component traits in Chilli (Capsicum annuum var. longum (dc.) sendt.). Electron. J. Plant Breed. 6 (2): 472-478.

Poehlman JM, Sleper DA. 1995. Field Crops. Iowa State University Press, United States of America

Senapati BK, Sahu FK, Sarkar G. 2003. Genetic divergence in chilli. Crop Res. Hisar. 26 (2): 314-317.

Sharma M, Sridevi O. 2016. Genetic variability, correlation and pathcoefficient analysis for yield and yield related traits in Chilli (Capsicum annuum L.). Adv. in Life Sci. 5 (1): 144147.

Singh RK, Chaudhury BD. 1985. Biometrical method in quantitative genetics analysis (rev. ed.). Kalyani Publishers, New Delhi, India, p. 78-85.

Singh SK, Sachan CP. Dubey AK. 2013. Genetical Studies on Chilli. Annals of Hort. 6:164-169

Sivasubramaniah S, Meron M. 1973. Heterosis and in breeding depression in rice. Madras Agril J. 60: 1139-1144.

Syukur M, Sujiprihati S, Yunianti R. 2012. Estimation of genetic parameter for quantitative characters of pepper (Capsicum annuum L.). J. Trop. Crop Sci. 1: 4-8

Ukkund MB, Krishna C, Madalageri MP, Mulage PR, Kotlkal YK. 2007. Variability studies in green chilli. Kar. J. Agril. Sci. 20 (1): 102-104

Wahyuni Y, Ballester AR, Tikunov Y, De Vos RC, Pelgrom KT, Maharijaya A, Sudarmonowati E, Bino RJ, Bovy AG. 2013. Metabolomics and molecular marker analysis to explore pepper (Capsicum sp.) biodiversity. Metabolomics. 9: 130144.

Wright S. 1921. Correlation and causation. J. of Agril. Res. 20: 557-585.

Yatung T, Dubey RK, Singh V, Upadhayay G, Pandey AK. 2014. Selection parameters for fruit yield and related traits in Chilli (Capsicum annuum L.). Ban. J. Bot. 43 (3): 283-291. 